\title{
Preference of Tourists toward Peace Tourism Product for Ground Zero Monument in Kuta Bali
}

\author{
Nyoman Ariana*, Made Sukana, I Nyoman Jamin Ariana
}

Faculty of Tourism, Udayana University, Bali, Indonesia

\begin{abstract}
The purpose of this study is to analyze the preferences of tourists toward the development of Ground Zero Monument as a peace tourism product in Kuta Bali. Samples of research is determined by purposive sampling, as many as 100 tourists. Data was analyzed by method of conjoint analysis. The results showed that it is necessary to offer statue of monument (miniature) and the history book of monument as a souvenir for the tourists, provide adequate monument facilities, give a special place for tourists to pray, package products to accommodate the values of peace symbols, design package monument tour that is interesting for the tourist by providing interpreters (guides to explain the monument), and it is not necessary to provide the transportation for the tourist because they are more likely to use private transport. While the level of interest rates in the product of peace tourism in Monument Ground Zero from highest to lowest based on the attribute utility value is as follows: souvenirs (16.509\%), physical attractiveness (15.775\%), services (14.889\%), non-physical attractiveness (14.461\%), facilities (13.820\%), attractions (12.648\%), and transports (11.898).
\end{abstract}

Keywords: Monument, Peace, Preferences, Tourism, Tourists.

\section{INTRODUCTION}

The development of peace through tourism in the history of academic is slightly created by tourism experts. One expert who studied peaceful tourism is Salazar in 2006 to focus his studies on Building a Culture of Peace through Tourism [1]. In addition to these ideas, opinions in building peace tourism also are proposed by the two national leaders: firstly, the former of President Megawati Sukarno Putri introduce peace through tourism in grand event ATF (Asian Tourism Forum) in Yogyakarta in 2005. While President Susilo Bambang Yudhoyono provides an appreciation of tourism, that peace can be achieved through the development of tourism. The presidential statement was delivered at the inauguration of the Institute of Peace and Democracy [2].

Tourism Destination of Kuta is one of the most famous of tourist attraction in Bali and is one of a magnet for foreign tourists who have been known since the early history of the development of tourism in Bali (since 1920). Kuta as excellent tourism destination in Bali is appropriate as a trade mark and a window in the international tourism in Bali (The Window of Tourism for Bali)[3]. Exploring and packaging of peace potential as a new tourist product that is

\footnotetext{
* Correspondence address:

Nyoman Ariana

Email : ramabharga@gmail.com

Address : Jl. Kampus Bukit Jimbaran, South Kuta, Bali.
}

used to counterweight cover the condition of current Kuta tourism. Some research suggests that Kuta has a relatively high crime rate [4]. Besides these findings, there are some negative impacts of tourism on the Kuta communities are: people's lifestyles tend to imitate western style, collectivity replaced individual characters, transformation of land, and unfair competetion in the business world [2].

Both study of tourism from the positive and negative impacts related to socio cultural and economic. Infact there are still opportunities in the Kuta area to build tourism that leads to wisdom (peacefulness) and uniqueness of the local communities. There are several reasons that reinforce those reasons, i.e. their history of interethnic acculturation, the establishment of Ground Zero monument as a monument of peace, and the high activity of the traditions and the application of philosophical values of resident. Exploring the potential of new tourism particularly on community value and essence in tourism, showed fundamental change from the stage of tourism development which often popularized by the tourism style [5]. It used to lead to the development of mass tourism, furthermore became tourism treat which leads to utilization of culture quality (cultural tourism). This change does not stop at the central, but also experienced a shift towards creativity in new venture packaging business on tourism. The real packaging leads to new experiences based products of peace tourism. 
It is very necessary to conduct research related to humanitarian values (humanist) such as: solidarity, justice, harmony, democracy, and friendship through the utilization of Ground Zero Monument to serve as a symbol of peace for the development of tourism towards peace in tourism destination of Kuta. Thus the monument is not only longer remembered as the place gave rise to hatred and revenge, but it could be selfintrospection to develop tourism in accordance with the values and culture of nation. It is also learn to a sense of compassion with echoes of peace through tourism development. Based on that systematic thinking, the aim of this study is to analyze the preferences of tourists through tourism products of peace in Ground Zero Monument Kuta Bali.

\section{MATERIALS AND METHODS}

This research was conducted at Ground Zero Monument in Kuta, Badung Regency, Bali Province. There are several reasons for choosing the location of this research: this monument as the only memorial Bali bombing tragedy; Kuta as an excellent tourismdestination in Bali, Kuta has heterogeneous society; Kuta known as a friendly and exotic destination; and the monument is visited by many tourists both domestic and foreign.

Preferences of tourists against peaceful tourist product are a package of products/ services both physical and nonphysical which will be offered to tourists at Ground Zero Monument. The limitation of study variables tourists preference againts peacefully tourism products which can be divided into several parts such as: seven (7) variables and 14 (fourteen) indicators (Table 1). The number of variables included: (1) physical attractiveness (design and arrangement of the monuments and architectural monuments; (2) non-physical attractiveness (pluralism and harmonization and a symbol of peace); tourism activities (praying and sightseeing); facilities (public and monuments); transport (public transport and private vehicles); souvenirs (CD \& t-shirt monument and miniature monuments and history); services (interpreter (guides) and individually.

The analysis used in this study is the conjoint analysis. A very precise conjoint analysis is used to examine the effects of the attributes of an object or service simultaneously to the person's preference for certain objects or services [6]. While other study explained conjoint is an attempt to evaluate the value of the product/ service/idea (real or hypothetical) by combining a number of value offered of each attribute [7]. Basically utility is the concept of measuring the value of conjoint analysis, the evaluation is unique from every individual subjectively. In the conjoint analysis, the utility is using the assumptions underlying the value in each level in every attribute and shows how the interrelationships utility formulated for combination of many attributes. To facilitate this research analysis process is assisted by using SPSS version 19.

Table 1. The Variables of Research

\begin{tabular}{lcl}
\hline \multicolumn{1}{c}{ Atribute } & Level & \multicolumn{1}{c}{ Sub-atribute } \\
\hline Physical & 1 & A1. Monument Design \\
Attraction & 2 & A2. Monument Architure \\
\hline Non Physical & 3 & B1. Pluralism dan Harmonization \\
Attraction & 4 & B2. Symbol of Peacefullness \\
\hline Tourism & 5 & C1. Prayer \\
Activities & 6 & C2. Sightseeing \\
\hline Facilities & 7 & D1. Public \\
& 8 & D2. Monument \\
\hline Transporta- & 9 & E1. Public Transport \\
tion & 10 & E2. Private Vehicle \\
\hline Souvenir & 11 & F1. CD and Monument T-Shirt \\
& 12 & F2. Miniature of Monument and \\
& & History \\
\hline Services & 13 & G1. Interpreteter (Guide) \\
& 14 & G2. Individually \\
\hline
\end{tabular}

\section{RESULT AND DISCUSSION}

Peace Tourism

Peace cannot be seen directly and relatively is difficult for measuring. However, peace can be interpreted as an action/behavior that the absence of war, terrorism, and violence. This view is completed by giving a definition that peace of tourism (tourism peace) is a new concept in the scientific of tourism. Peaceful tourism can be defined as a freedom, peace and without wars are constructed from inner peace, natural environment and God [1].

Tourism is very potential made an effort to promote the value of peace to the local community. For example, the tourism activity was found to reduce inter-state conflict between South Korea and North Korea [8]. The good ways to create peacefulness is to build tourism through making combination strategy of government policy, political and cultural values [9].

Other finding about the definition of peaceful tourism is tourism development that accelerates mutual understanding in the society [10]. Tourism development that takes into account the strength of tourism will be able to help human kind to a life of peace and harmony. 
Tourist Preference for Peace Tourism Products

The main analytical tool used in this research is the conjoint analysis. The analysis assumes that peaceful tourist product can be defined as a series of level-specific attributes, as well as utilities tourists choice in all is determined by the partial utilities (part-worth) which further contributed by each level attribute in a peaceful tourist product. This analysis can provide a combination of attributes identifying a peaceful tourism of the most preferred by tourists and the identification of the relative importance of each attribute/ variable.

The purpose to limit the number of attributes and the level used to avoid complications in processing the data. With a limited number of tourists it will be easier to choose a combination of stimuli in ranking. In this study, we used seven attributes/variables and 14 sub attribute (level) (Table 2). Possible combinations are formed from different of sub attributeare128 stimuli.
Theoretically, we should assess 128 stimuli with a combination of attributes each of which is impractical and difficult for the respondent/ tourists. Therefore, it is used in a way that is orthogonal procedure (SPSS) to help create a combination of stimuli of 8 possibilities, so not all combinations should be analyzed further (Table $3)$, thus we found eight stimuli. The stimuli are then represented into eight types of peace tourism products which each have different attribute combinations.

The perceptions of respondents are sorted to mark the types of tourism products peace most preferred (1) to the other tourism products peace least preferred (8). The choosing of tourist is referred to as utility expressed with numbers and forms the basis conjoint in tracking preferences. Tourist preferences in choosing a travel product peacefully found that the attributes and sub-attributes preferred by tourists are as follows.

Table 2. Orthogonal Procedure: Stimuli for Preferences of Peace Tourism Product

\begin{tabular}{|c|c|c|c|c|c|c|c|}
\hline Stimuli & $\begin{array}{c}\text { Physical } \\
\text { Attraction }\end{array}$ & $\begin{array}{c}\text { Non Physical } \\
\text { Attraction }\end{array}$ & Activities & Facilities & $\begin{array}{c}\text { Transport } \\
\text { ation }\end{array}$ & Souvenir & Service \\
\hline 1 & $\begin{array}{l}\text { Monument } \\
\text { Design }\end{array}$ & $\begin{array}{l}\text { Pluralism and } \\
\text { Harmonization }\end{array}$ & Sightseeing & Public & $\begin{array}{l}\text { Public } \\
\text { Transport }\end{array}$ & $\begin{array}{l}\text { Monument Miniature } \\
\text { and History }\end{array}$ & Individually \\
\hline 2 & $\begin{array}{l}\text { Monument } \\
\text { Architecture }\end{array}$ & $\begin{array}{l}\text { Pluralism and } \\
\text { Harmonization }\end{array}$ & Prayer & Monument & $\begin{array}{l}\text { Private } \\
\text { Vehicle }\end{array}$ & $\begin{array}{l}\text { Monument Miniature } \\
\text { and History }\end{array}$ & Interpreter \\
\hline 3 & $\begin{array}{l}\text { Monument } \\
\text { Design }\end{array}$ & $\begin{array}{l}\text { Symbol of } \\
\text { Peace }\end{array}$ & Prayer & Monument & $\begin{array}{l}\text { Public } \\
\text { Transport }\end{array}$ & $\begin{array}{l}\text { Monument Miniature } \\
\text { and History }\end{array}$ & Individually \\
\hline 4 & $\begin{array}{l}\text { Monument } \\
\text { Design }\end{array}$ & $\begin{array}{l}\text { Pluralism and } \\
\text { Harmonization }\end{array}$ & Prayer & Public & $\begin{array}{l}\text { Public } \\
\text { Transport }\end{array}$ & $\begin{array}{l}\text { CD and Monument } \\
\text { T-Shirt }\end{array}$ & Interpreter \\
\hline 5 & $\begin{array}{l}\text { Monument } \\
\text { Architecture }\end{array}$ & $\begin{array}{l}\text { Pluralism and } \\
\text { Harmonization }\end{array}$ & Sightseeing & Monument & $\begin{array}{l}\text { Public } \\
\text { Transport }\end{array}$ & $\begin{array}{l}\text { CD and Monument } \\
\text { T-Shirt }\end{array}$ & Individually \\
\hline 6 & $\begin{array}{l}\text { Monument } \\
\text { Architecture }\end{array}$ & $\begin{array}{l}\text { Symbol of } \\
\text { Peace }\end{array}$ & Prayer & Public & $\begin{array}{l}\text { Private } \\
\text { Vehicle }\end{array}$ & $\begin{array}{l}\text { CD and Monument } \\
\text { T-Shirt }\end{array}$ & Individually \\
\hline 7 & $\begin{array}{l}\text { Monument } \\
\text { Design }\end{array}$ & $\begin{array}{l}\text { Symbol of } \\
\text { Peace }\end{array}$ & Sightseeing & Monument & $\begin{array}{l}\text { Private } \\
\text { Vehicle }\end{array}$ & $\begin{array}{l}\text { CD and Monument } \\
\text { T-Shirt }\end{array}$ & Interpreter \\
\hline 8 & $\begin{array}{l}\text { Monument } \\
\text { Architecture }\end{array}$ & $\begin{array}{l}\text { Symbol of } \\
\text { Peace }\end{array}$ & Sightseeing & Public & $\begin{array}{l}\text { Public } \\
\text { Transport }\end{array}$ & $\begin{array}{l}\text { CD andMonument } \\
\text { T-Shirt }\end{array}$ & Interpreter \\
\hline
\end{tabular}

Table 3.AssessmentRatingandUtilitiesGeneralPreferencesof Peace Tourism Product

\begin{tabular}{llrl}
\hline \multicolumn{1}{c}{ Attribute } & \multicolumn{1}{c}{ Sub-Attribute } & Utility & Preference \\
\hline Physical Attraction & Monument Design & -.067 & \multirow{2}{*}{ Monument Design } \\
& Monument Architure & .067 & \\
\hline Non Physical Attraction & Pluralism dan Harmonization & .210 & \multirow{2}{*}{ Symbol of Peacefullness } \\
& Symbol of Peacefullness & -.210 & \\
\hline Tourism Activities & Prayer & -.257 & \multirow{2}{*}{ Prayer } \\
& Sightseeing & .257 & \\
\hline Facilities & Public & .302 & \multirow{2}{*}{ Facilities of Monument } \\
& Facilities of Monument & -.302 & \\
\hline Transportation & Public Transport & .042 & \multirow{2}{*}{ Private Vehicle } \\
& Private Vehicle & -.042 & \\
\hline Souvenir & CD and Monument T-Shirt & .330 & \multirow{2}{*}{ Miniature of Monument and History } \\
& Miniature of Monument and History & -.330 & \\
\hline Services & Interpreter (Guide) & -.050 & \multirow{2}{*}{ Interpreter (Guide) } \\
& Individually & .050 & \\
\hline (Constant) & & 4.490 & \\
\hline
\end{tabular}


First, souvenir attribute has the highest percentage of the relative importance (16.51\%). Associated with tourists sub attribute that like statues and historical monuments (score of -0.33) more compared with $\mathrm{CD}$ and T-shirt Monument (0.33). Second, physical attractiveness with relative importance value $15.78 \%$ is the design and arrangement of the monument (0.069) compared with the architecture of the monument (-0.067). Third, the service attribute with $14.89 \%$ relative importance, respondents preferred the interpreter services (guides) $(-0.050)$ than self-service by tourists (0.050).

Fourth, non-physical attractiveness relative importance value $14.46 \%$ of the respondents preferred the peace symbol $(-0.210)$ than pluralism and harmonization (0.210). Furthermore, the attribute of facilities (13.82\%)was preferred the monument facilities $(-0.302)$ than public facilities $(-0.302)$. Sixth tourist attraction with $12.65 \%$ value relative importance, respondents prefer to pray $(-0.257)$ compared with the sightseeing (0.257). Lastly, transport attribute with a value of $11.89 \%$ interest, respondents preferred private vehicles $(-0.042)$ compared with public transport (0.042). For more details see Table 3 and Table 4.

Pearson and Kendall correlation (Table 5) are above 0.5 indicate a strong relationship between the estimated and factual variable. It means that the regression model strongly correlate with the opinion on the choice of travel products. Significance test obtained below 0.05 (Table 4), means the correlation is significant.

\begin{tabular}{lc}
\hline \multicolumn{1}{c}{ Table 4. Importance Values of Peace Tourism Product } \\
\hline \multicolumn{1}{c}{ Attribute } & Importance Values (\%) \\
\hline Physical Attraction & 15.78 \\
Non Physical Attraction & 14.46 \\
Tourist Activities & 12.65 \\
Facilities & 13.82 \\
Transportation & 11.90 \\
Souvenirs & 16.51 \\
Services & 14.89 \\
\hline
\end{tabular}

Table 5.Correlations between observed and estimated preferences

\begin{tabular}{ccc}
\hline Method & Value & Sig. \\
\hline Pearson's R & 1.000 & .000 \\
Kendall's tau & 1.000 & .000 \\
\hline
\end{tabular}

\section{CONCLUSION}

The tourist preferences towards product on a peace tour Ground Zero Monument Kuta Bali suggest that it is necessary to provide statue of monument (miniature) and the history book of monument as a souvenir, provide adequate monument facilities, Provide praying place for travellers, package products to accommodate the values of peace symbols, design and arrange good and interesting pack, need to provide interpreters (guides to explain) of monument. It is unnecessary to provide the transportation vehicles because tourists are more likely to use private vehicles. The level of interest in the peaceful tourist product in Monument Ground Zero from highest to lowest based on the attribute utility value is as follows: souvenir), physical attractiveness, services, non-physical attractiveness, facilities, attractions, and transport.

\section{REFERENCES}

[1] Salazar, N. B. 2006. Building a culture of peace though tourism: reflexive and analytical notes and queries. Fcs, Facultad De Ciencias Sociales, 62. Available at: http://www.javariana.edu.co.

[2] Ariana, N. 2011. The opportunities of peace tourism for Bali. In: Putra, D. and IG. Pitana (Eds). Hyperdemocracy on tourism development for appreciating Prof. Ida Bagus Adnyana Manuaba. Pustaka Larasan. Denpasar. 71-86.

[3] Pitana, IG., N. Sirtha, A. A. G. P. Agung, W. S. Astiti, W. P. Artini, N. Sunarta. 2000. Kuta as a broken mirror of Bali tourism. Bali Post. Denpasar, Bali.

[4] Mahagangga, O. 2011.The challenges of Bali tourism safety: criminal mapping studies in Bali tourism destination. In: Putra, D. and IG. Pitana (Eds). Hyperdemocracy on tourism development for appreciating Prof. Ida Bagus Adnyana Manuaba. Pustaka Larasan. Denpasar. 71-86.

[5] Richards, G. and J. Wilson. Tourism, creativity and development. Rutledge. USA and Canada.

[6] Gudono. 2012. Multivariate data analysis. BPFE. Yogyakarta.

[7] Hair, J. F. and R. E. Anderson. 1998. Data analysis. Prentice Hall Inc. New Jersey. USA.

[8] Kim, S. S., B. Prideaux, J. Prideaux. 2007. Using tourism to promote peace on the Korean Peninsula. Annal of Tourism Research 34 (2), 291-309.

[9] Ki, L. C., L. J. Bendle, Y. S. Yoon and M. J. Kim. 2011. Thana tourism or peace tourism: perceived value at a North Korean Resort from indigenous perspective. International Journal of Tourism Research 14(1), 71-90.

[10] Damore, L. 1998. Tourism-the world peace industry. Journal of Travel Research 27(1), 35-40. 